will be seen on an inspection of this map that the quartzite series is represented as terminating obliquely against the margin of the granite or gneiss. This obliquity has never (as far as I can discover) been explained. The prevalent opinion seems to have been that the newer series has been converted into the older by increased metamorphic action. For some time past I never studied Griffith's map without the impression that the obliquity was due to unconformity of stratification, and on the determination of this point plainly rested the question whether the granitoid gneiss was, or was not, of Laurentian (or "Archæan") age.

Having had the advantage of a visit to some of the sections in the North Highlands of Scotland, in company with my colleague, Mr. R. G. Symes, under the able guidance of Prof. Geikie, last summer, I was in a position much more favourable for undertaking the investigation of this interesting question than would otherwise have been the case; and in the recent visit to Donegal I was accompanied by Mr. Symes and Mr. Wilkinson, of the Irish Survey, who rendered material aid in this preliminary survey.

The knowledge thus obtained has been of essential service, and I am happy to be able to state that we have succeeded in identifying the Donegal gneissic series, both as regards its mineral characters and its unconformable relations to the Lower Silurian series with the Laurentian beds of Sutherland and Ross. The relations of the two series in Donegal are similar to those which are to be observed in the Laxford and Rhiconich districts, where the Cambrian sandstones and conglomerates are absent, and where, in consequence, the Lower Silurian quartzites and limestones rest directly on the old gneiss. These conditions can be clearly made out in the neighbourhood of Lough Salt, near Glen, where successive beds of quartzite, limestone, diorite, and schist of the Lower Silurian series terminate abruptly at the margin of the gneissic series. We satisfied ourselves that this truncation of the Silurian beds is not due to faulting, as there is no appearance of disturbance or fracturing amongst the strata on either side. Similar-though less clear-indications were observable all along the eastern or southern margin of the gneissose district. Nor was the unconformity confined to the Silurian series, as we found that the beds of this formation came into contact with these of different geological horizons amongst the greissic series at different places; there occurs, in fact, a double unconformity.

When examining the gneissic series we were often struck by the resemblance presented by the beds to those of Sutherlandshire, particularly amongst the lower portions. The massive foliated rock formed of red orthoclase, greyish oligoclase, green and black mica, and quartz, traversed by pegmatite veins, is identical in character with that from Rhiconich and Laxford; while the upper beds are interstratified with hornblendic and micaceous schists like those near Scourie. The occurrence of thin beds of white and grey marble, with sphene, idocrase, \&c., in the Laurentian gneiss, seems peculiar to the Irish rocks, and brings them into close relationship with those of Canada.

A new basis has thus been formed for the whole superstructure of the Irish geological formations as deeply seated as that of any other country, and there can be little doubt that as the Laurentian beds have thus been recognised on the clearest evidence in Donegal, they may be recognised also in parts of Sligo, Mayo, and Galway, where the evidence is not so clear.

As I hope to have an opportunity of more fully stating the case at the forthcoming meeting of the British Association at York, it will be unnecessary here to enter on further details. I will only add that in speaking of the gneissic series as "Laurentian" I only wish it to be understood that the beds are contemporaneous with those underlying the Cambrian and Lower Silurian series of the Scottish Highlands. Whether they are really the representatives in time of the Laurentian beds of Canada is immaterial for my present purpose. For my own part I consider the preponderance of the evidence to be in favour of the view that they are in the main representative.

Geological Survey Cffice, Dublin

\section{JOSEPH BARNARD DAVIS}

A FTER a short illness Dr. J. Barnard Davis died last week at his residence at Hanley, Staffordshire, being about eighty years of age. In the summer of 1820 , while still a student, he made a voyage to the Arctic regions in the capacity of surgeon to a whaling ship. In 1823 he became a licentiate of the Society of Apothecaries; twenty years later he passed the College of Surgeons, and in 1862 took the M.D. degree of the University of St. Andrew's. In 1868 he was elected into the Royal Society. Soon after obtaining his first qualification he settled down in the Potteries, and but for what he describes, in the preface to his "Thesaurus Craniorum," as "an accidental conversation with a friend," might have remained through life leading the useful but uneventful life of thousands of general practitioners in the country, unknown beyond his immediate sphere of work. That accidental conversation however lighted up some smouldering embers of an interest which long before had been kindled by the lectures of Lawrence on the Natural History of Man, and led to the researches which resulted in the publication (in conjunction with the late Dr. Thurnam) of the "Crania Britinnica," or delineations and descriptions of the skulls of the aboriginal and early inhabitants of the British Islands, illustrated with sixty-seven beautifully-executed lithographic plates, completed in 1856 . Besides this Dr. Davis published many memoirs on anthropological subjects, jncluding one "On Synostotic Crania among Aboriginal Races of Man," one on "The Osteology of the Tasmanians," one on "The Peculiar Crania of the Inhabitants of Certain Groups of Islands in the Western Pacific," and one published in the Philosophical Transactions for 1868 , "On the Weight of the Brain in different Races of Man."

But it was by his famous collection, rather than by his writings, that Dr. Barnard Davis was best known, and the time, labour, and money which he spent in gathering it together is his greatest service to science. During a long period of time, in which the national and other public collections were losing the golden opportunities afforded by the extension of English adventure and commerce to all parts of the world, and allowing races to die out or their characteristics to become obliterated by intermixture with others, Dr. Davis let no chance of procuring specimens pass by, and was unwearied in his correspondence with travellers, collectors, and residents in foreign lands. He thus amassed together within a few rooms of a small house in Staffordshire a collection of crania and skeletons, nearly all with carefully-recorded histories, far exceeding in size that in all the public museums of the country put together, and only surpassed in very recent years by any of the Continental collections. In 1867 be published a catalogue called "Thesaurus Craniorum," which not only contains a description and many figures of the specimens, with 25,000 measurements, but which is also a perfect storehouse of information, owing to the literary references with which it abounds. The publication of this catalogue made the collection so well known that it naturally led to its increase, and in 1875 it became necessary to publish a supplement on the same plan, in which the history of the literature of the subject was continued to date. The catalogue and supplement contain descriptions of more than 1700 specimens, mostly crania.

Warned by failing health and increasing years of the 
desirability of making arrangements for the future preservation of the collection, Dr. Davis entered into negotiations about a year ago with the College of Surgeons of England, by which body it was purchased, and in whose museum it has now been arranged in such a manner as to be accessible to all workers at anthropology. Such a collection as this, well cared for in a public museum, is a solid and permanent increase to the wealth of the country, for even if the methods of investigation now used are superseded by others, and the present literature comes to be looked upon as obsolete, the specimens will remain as materials for building up the history of the human race; and as the interest in the subject increase - -as it certainly will--many of these evidences of the physical structure of people passed or passing away will come to be objects of priceless value.

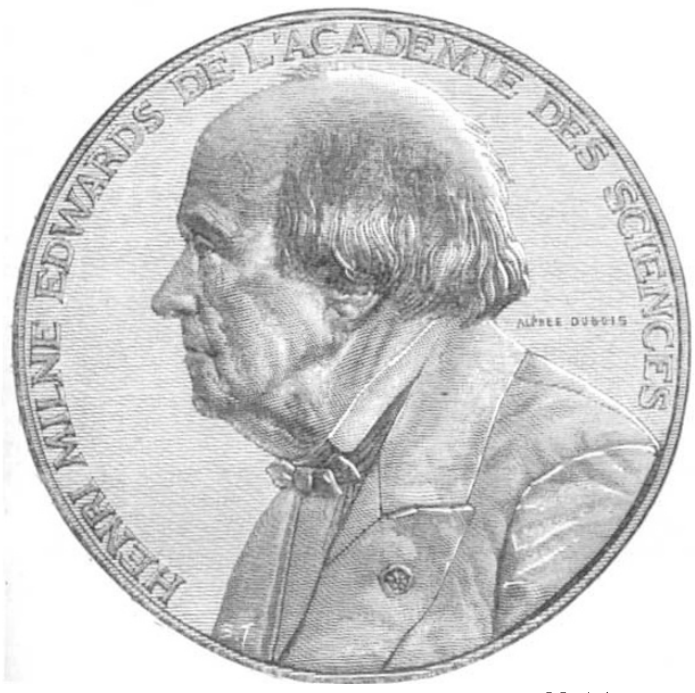

\section{H. MILNE-EDWARDS}

WE referred some time ago to the fact that a medal, subscribed for by a number of his admirers, had been presented to the venerable zoologist, M. H. MilneEdwards. No one better deserves such a recognition.

Medal presented to M. H. Milne-Edwards.

and none know better than the French how to do such an honour gracefully and impressively. Our illustration is reproduced from La Nature of May 7, where will be found a pretty complete list -and it is a long one-of $M$. Milne-Edwards' works. The medal, a production of some artistic merit, is the work of M. Alphée Dubois.

\section{THE ZOOLOGICAL RESULTS OF THE SOCOTRAN EXPEDITION}

$\mathrm{A}^{\mathrm{T}}$

the meeting of the British Association in 1878 , upon the motion of Mr. Sclater, a Committee, consisting of Dr. Hartlaub, Sir Joseph Hooker, Capt. J. W. Hunter, Prof. Flower, and the mover, was appointed to take steps for the investigation of the natural history of Socotra. Socotra, it was stated, was one of the few spots in the world which seemed never to have been trodden by the foot of the naturalist, and would in all probability be found to contain distinct insular forms, of which it would be highly interesting to know the relations, and to secure specimens for our collections.

The grant of Iool., given by the Association for this excellent object, having been subsequently increased by two sums devoted to the same purpose out of the Government Fund of $4000 \%$. administered by the Royal Society, the Committee felt strong enough to proceed to action, and in the winter of 1879 were fortunate enough to secure the services of Prof. J. B. Balfour, of the University of Glasgow, for a special expedition to the island.

Prof. Balfour left England on January 9, I880, accompanied by Alexander Scott, a gardener from the Royal Botanic Gardens, Edinburgh, as collector, and reached Aden by the French mail on the 24 th, where he obtained every sort of advice and assistance from the civil and naval authorities for his expedition. Owing to adverse winds and other difficulties Prof. Balfour did not manage finally to reach Socotra until February in, when the party, which had been reinforced by the addition of Lieut.
Cockburn of the 6th Royals and a corps of attendants from Aden, were put on shore at Gollonsir, a village situated at the north-west end of the island, by H.M.S. Seagull. In his report to the. Socotran Committee Prof. Balfour gives the subjoined account of his subsequent proceedings :-

"Making in the first instance Gollonsir our headquarters, we explored the adjacent country to the south and south-west until February 25, when we struck tents, and sending our heavy baggage and stores by sea, started to march to Hadibu. We took four days to accomplish this, reaching Hadibu late on the night of the 28 th inst.

"Having communicated to the Sultan the fact of our arrival, he came to Hadibu on March 1 , when we had an interview.

"Establishing our depôt now on the Hadibu plain, about a mile from the town, we spent the time until the 7 th inst. investigating the magnificent Haggier range of hills shutting in on the south the Hadibu plain.

"On March 8, leaving a tent-Lascar in charge of the depôt at Hadibu, we started upon a trip to the eastern end of the island, going eastward along the northern side and returning westward by the southern side of the island. During this trip we reached Ras Momé, the extreme eastern headland. Camp at Hadibu was again entered on March 18.

"As yet we had not seen much of the southern parts of the island, so on March 22 we left Hadibu on our last excursion. Crossing the Haggier range we emerged upon the southern shore at Nogad, traversed the coast-line for some distance, and then recrossed the island so as to 